\title{
LAND TENURE IN HYDROPOWER DEVELOPMENT: A REVIEW
}

\author{
Subash Ghimire \\ Assistant Professor, Department of Civil and Geomatics Engineering, Dhulikhel, Nepal \\ Corresponding address: subash_ghimire@ ku.edu.np \\ Received 29 April, 2012; Revised 29 July 2012
}

\begin{abstract}
Land tenure issues such as tenure forms and its allocation and land acquisition procedure are not extensively considered in hydropower development. As a result hydropower projects are not sustainable. The main aim of the study is to find the role of land tenure in hydropower development. Desk study is carried out and is followed by the scientific literature review. The study reveals that the concession with broader negotiations and agreements is carried out for interfering the land rights for the construction of hydropower project in Norway because of which the Aurland hydropower project got successful. The capability and economical willingness to include land and environmental issues from the start of the project to operation stage made the development successful while concession is practiced in China without broader negotiations and public participation as in Nu river project. Therefore, a Chinese hydropower concession is controversial. Many of the proposed dam is situated in UNESCO world heritage site and in the conservation area. $\mathrm{Nu}$ river project affects number of distinct ethnic groups who maintain their religious and cultural tradition. Resettlement is not possible on this ethnic group because of integration into population of various customs, languages and agricultural tradition. In case of Nepal in general, concessions is not practiced during hydropower development. Transparency in information dissemination, decision making, involvement of key stakeholders on key issues and time bound solution can hardly be found during hydropower development. Mostly, land is expropriated for the development of the hydropower project. The study finds that Land tenure has very important role in hydropower development. Therefore, it should be extensively considered for sustainable development of the hydropower projects.
\end{abstract}

Keywords: Land Tenure, Hydropower development, Land Acquisition

\section{INTRODUCTION}

Land tenure as one of the key component of land administration plays very important role for the sustainability of the environment and hydropower projects itself. Land tenure is the relationship which may be defined legally or customarily among people with respect to land [1]. This relationship may be categorized as man to land relationship, man to man relationships and land to land relationships [2]. It is different in different countries even varies within a country. According to [3], cultural, political, economic situations, social systems etc. have influenced these different arrangements. Imposing a certain land use to private owners interferes in the characteristics of the private property rights, also called the 'bundle of rights' that constitute a private property right.

Considering economical, technical, and environmental benefits, hydropower can be a very important contributor to meet the future energy needs in developing countries. They have a great need for electricity and also have the largest remaining hydropower potential [4]. Indeed, many 
countries look upon hydropower as a key to their future economic development. Hydropower consisting of major components like dam, intake, canal, desander basin, fore bay, penstock, powerhouse, tail race, transmission line etc. is the main source of electrical energy of Nepal. Nepal is one of the Himalayan countries with a high power potential. It has theoretically hydropower potential of $83,000 \mathrm{Mw}$ and economical potential of 43,000 Mw. At present, the installed capacity of hydropower is less than $1000 \mathrm{Mw}$, less than $2 \%$ of the total economically feasible potential [5]. Less than $40 \%$ of Nepalese currently have access to electricity and those who do have electricity are reeling under a load shedding schedule. The country now move forward to enhance her strength and mitigate the risks involved realizing: Nepal KO Pani, Pragati KO khani (Literally: 'Nepal's water, Source of national development').

The Bathurst declaration mentions that "Sustainable development is not attainable without sound land administration"'[6]. On this background, there is an urgent need for the country to develop a sustainable path for the generation of energy which has direct relations on land tenure to benefit the country.

The main aim of the study is to find out the role of land tenure in hydropower development. The tenure forms and allocations and land acquisition procedures in hydropower development in planning and implementation are reviewed for the study. Land tenure in hydropower development in Norway, China and Nepal are reviewed is reviewed to know the good and weak practices in different hydropower projects. Land tenure experiences of only these countries is reviewed because of various form of land ownership and its allocation, land acquisition procedure during hydropower development in different countries.

\section{MATERIAL AND METHODS}

The desk study is carried out and is followed by the scientific literature review in the field of land tenure in hydropower development. Scientific literature such as journal articles, conference papers, books and documents including research/project reports are used for the purpose of this study and are mentioned in reference section.

\section{LAND TENURE AND LAND ADMINISTRATION IN HYDROPOWER DEVELOPMENT}

The importance of land tenure and Land Administration (LA) in all stages of hydropower development is for the sustainability of the hydropower project. The sustainability of the hydropower projects creates economic development which ultimately enhances the poverty reduction in the country. Therefore, efficient and effective LA is very essential for sustainable development [7].

In political decision making stage of hydropower development, LA is capable to support the ever changing relationship between land and humankind to promote complex decision making. Hydropower developments that contribute to successful land use require LA to balance private rights in planning and feasibility stage. The most important incentive for investment in land is high perception of land tenure security. If the perception of land tenure security is weak, investors are not investing since there might be risk to get profit from the investment. Land tenure security supports transferability of land, greater investment incentive, more sustainable 
management of land resources etc. The sound LA with appropriate parcel based geo information system is very essential for the people and government to ensure good tenure security with efficient and effective land transactions [2]. In the design stage, LA supports by fostering good governance and stakeholders expectation. In implementation stages, LA supports in land acquisition by providing the proper information of land ownership, land value and land use. In operation stage, LA supports for improving the social and environmental impacts taking account on the stakeholders' satisfaction.

LA for sustainable development is very essential for anyone interested in environment and resource management, economic development and balancing property rights [8]. Therefore, LA should be focused in all stages of hydropower development.

\section{LAND TENURE IN HYDOPOWER DEVELOPMENT: AN EXPERIENCES}

These are discussed in the headings Land tenure in hydropower development in Norway, China and Nepal.

\section{Land Tenure in Hydropower Development in Norway}

This section is discussed in two major land tenure issues; Tenure forms and its allocation and land acquisition.

\section{a) Tenure forms and its allocation}

Norway has private land, state land and common land and most of agricultural land has private ownership. There are also three main types of common land in Norway: state common land, parish common land, and land jointly owned by estates [9]. It has $37 \%$ forests lands, 3\% arable lands, $44 \%$ highlands, freshwater surface and wetlands and rest $16 \%$ glaciers, snowfields and talus slopes and about $96 \%$ of all farm units are owned by private owners.

The local commune has decisive influence in using and transferring of agricultural and forest land [10]. The common land and private land is allocated in development of Alta Hydropower project. It is allocated in forest land and arable land. Hydropower in Norway is assumed to be a natural as well as a local resource that involves comprehensive planning processes. According to [11], land use planning is well considered in Aurland hydropower development project. The various ways to minimize negative effect of construction on the cultural and natural landscape were considered in its development. These measures include extensive use of tunnels in road construction and re-vegetation of the disposal site and quarries. Because of technical development such as tunneling and underground constructions, the environmental impacts were also limited. Aesthetic aspect of the project area is maintained from this technical development because large part of the installations is not visible and results no impacts on the surroundings above earth. This hydropower development got success because local groups are involved for improved road construction and considers the land tenure during the planning of hydropower development. Access to information and compensation procedure was well planned and 
implemented during hydropower development. The capability and economical willingness to include land and environmental issues from the start of the project to operation made the development successful. The landscape before and after the vegetation in the quarry site of Aurland hydropower project is shown in the Figure 1.
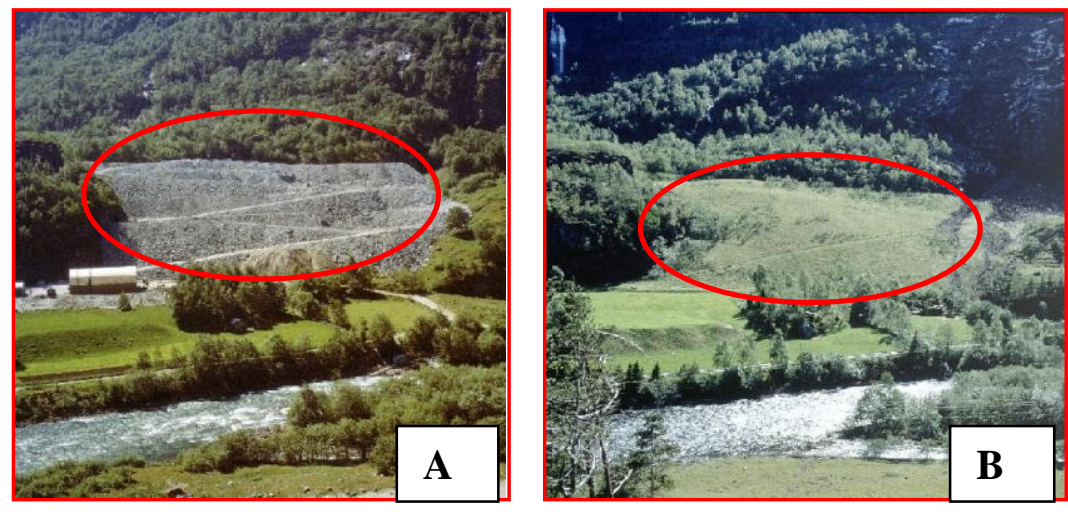

Figure 1. Rock deposit (A) before and (B) after vegetation (Photos: P.O. Breifjell)

\section{b) Land Acquisition}

The Watercourse Regulation Act grant permission for all hydropower projects with a concession to expropriate all essential rights needed to construct the project. Based on this law, any group is, in exchange for economic compensation, obliged to withdraw land and rights from landowner as needed to complete the hydropower project. The renouncing of land and related rights is negotiated in a non-controversial manner with negotiations and agreements. However, the law also includes the legal tool to expropriate if required and is carried out by the concession [12]. The project owner gives the considerable compensation to both the commune and affected families for acquirement of a locally available natural resource. Public participation and access to information is maintained during land acquisition.

\section{Land Tenure in Hydropower Development in China}

This section is also discussed in two major land tenure issues; Tenure forms and its allocation and land acquisition.

\section{a) Tenure forms and its allocation}

The land tenure system in China is based on written law: Constitution and Land Administration law of People's Republic of China. It can be divided into three types of right i.e. ownership, use and other rights that include mortgage, easement, lease etc. Two types of ownership of land are found in China i.e. state owned land and collective owned land [13]. Both collective owned and state owned land are allocated for the hydropower development [14]. Land use plan is not prepared in $\mathrm{Nu}$ river hydropower development. Many of the proposed dam is situated in 
UNESCO world heritage site and in the conservation area. $\mathrm{Nu}$ river project affects number of distinct ethnic groups who maintain their religious and cultural tradition. Resettlement is not possible on this ethnic group because of integration into population of various customs, languages and agricultural tradition [15]. Because of lack of access to information and transparency in planning processes [16], Nu river project faces obstacles in its development.

\section{b) Land Acquisition}

The compulsory acquisition of land has been in practice for hydropower development. State can acquire the collectively owned land and can change into the state owned land. The concessions procedure is also followed in hydropower development but it is without broader negotiations and agreements. Therefore, Chinese hydro concessions are controversial [17].During the resettlement better oversight is not done to reduce the negative economic effect of displacement in $\mathrm{Nu}$ river project. It consists of 13-dam cascade, one of the largest hydropower development projects yet assumed in China. Several violations of the rules and regulations during land acquisition and compensation were observed including the lack of provisions to enable residents to continue farming after resettlement and the lack of input regarding the settlement process from the affected families themselves. Since villagers are forced to leave agriculture production, the livelihood of the affected families has not improved during development of $\mathrm{Nu}$ river project.

\section{Land Tenure in Hydropower Development in Nepal}

This section is further discussed in two major land tenure issues; Tenure forms and its allocation and land acquisition.

\section{a) Tenure forms and its allocation}

Until 1950, Nepal had statutory tenure system and customary tenure system. Statutory tenure system involved Raikar, Birta, Jagir, Rakam, Jagera and Guthi whereas the customary tenure system involved Kipat land existed in the eastern hilly region of the country [18]. During 1950, land tenure system of the country has been changed into private land, state land i.e. public and government land and guthi land. Raikar, Birta, Jagir, Rakam, Jagera and kipat land are converted into private land. Birta abolition act 1959 was enacted to abolish the birta type of tenure system [2].

Private land, state land (government and public) and trust lands are allocated for hydropower development in the country. Hydropower project is allocated in agricultural land, forest land, barren land and pasture land. In Nepal, land use planning has not considered in hydropower development plan. Transparency in information dissemination, decision making, involvement of key stakeholders on key issues and time bound solution can hardly be found during hydropower development [19].Therefore, hydropower projects are not sustainable. An EIA is to be carried with a detailed project planning, monitoring and mitigation plan [20]. 


\section{b) Land Acquisition}

Mostly, land is expropriated for the development of the hydropower project. Regarding legal protection for ascertaining tenure security, [21] ensures the right to own, acquires, dispose and sell the real property as a fundamental right. It ensures protection from requisition acquires or creates any encumbrances without proper compensation and ensures equity in terms of religion, gender, ethnicity etc. to own land.

According to [22], in $144 \mathrm{Mw}$ Kali Gandaki 'A' hydropower project, Nepal Electricity Authority (NEA) acquired about 53.7 hectares of land and 57 houses for the access road. Similarly, 148.62 hectares land was acquired of which 94.2 hectares was private and guthi land for the main project features such as dam, powerhouse and site offices. An Acquisition compensation and rehabilitation plan (ACRP) is prepared as a project document following the process established in the Land Acquisition Act of Nepal. But institutional conditions like differentiating of affected people, low and unfair compensation, exclusion of directly affected families in compensatory procedures and lack of strong consultation processes enhances additional gaps that results instability amongst those affected by the dam intervention. Unless compensatory procedures are nicely laid out and implementation of plans is made transparent, hydropower projects are not sustainable in a developing country like Nepal with its limited land resources and intricacies of power within social relations [19].

\section{RESULTS AND DISCUSSION}

In developing countries tenure issues like tenure forms and its allocations and land acquisition procedure are not considered in planning hydropower development. Hydropower development plan mostly focus on technical components. Public participation is not broadly involved in the planning process of hydropower development. But in developed country, tenure issues are well considered in planning hydropower development. Social and environmental effects are considered from beginning of the project to the operation stage of hydropower development. Therefore, the projects are successful in developed country. It is noticed that different countries have different practices in planning hydropower development depending on their willingness and capability to consider the tenure issues in hydropower development plan. Private land, state land, religious land and common land are allocated for hydropower development in Norway, China and Nepal. Aurland Hydropower development in Norway is successful because of focusing of land tenure in its development. Land required for the construction of the project is acquired with the concessions based on broader agreements and negotiations in Norway. Comprehensive Land use planning was prepared during its development. Benefits of power output and project itself are shared to affected people and stakeholders are involved in the development process. In China and Nepal, mostly land is expropriated without comprehensive planning and broader participation of stakeholders.

\section{CONCLUSION}

The study concludes that different countries have different land tenure forms and its allocations and land acquisition procedure depending upon social, political and economical condition of the country. The country implementing public participation, broader agreements and negotiations in 
land acquisition got successful in hydropower development while others not implementing these issues don't get successful in its development. Therefore, Land tenure has very important role in making the hydropower projects sustainable. It should be focused in hydropower development plan for smooth development of the projects protecting cost and time overrun of the projects.

\section{ACKNOWLEDGEMENTS}

The author is greatly thankful to Kathmandu University (KU) and University of Twente, Faculty of Geo Information Science and Earth Observation, ITC, The Netherlands for their support to carry out the study.

\section{REFERENCES}

[1] FAO, Good governance in land Tenure and administration; FAO Land Tenure Studies 9, 2010, Retrieved August 19, 2010, from ftp://ftp.fao.org/docrep/fao/010/a1179e/a1179e00.pdf

[2] Tuladhar A M, Parcel- based geo-information system:Concepts and Guidelines, 2004, Available from http://www.itc.nl/library/Papers_2004/phd/tuladhar.pdf

[3] Agarwal B, A field of one's own:gender and land rights in South Asia,1996. Published by the Press Syndicate of the University of The cambridge, NY, USA.

[4] Klimpt, J-É, Rivero, C, Puranen, H, \& Koch F, Recommendations for sustainable hydroelectric development. [doi: DOI: 10.1016/S0301-4215(02)00092-7], 2002, Energy Policy, 30 (14), 1305-1312.

[5] Sangroula, D P Hydropower Development and Its Sustainability with Respect to Sedimentation in Nepal, 2009. Insitute of Engineering, 7, 1-9.

[6] UN/FIG Workshop on Land Tenure and Cadastral Infrastructures for Sustainable Development; the Bathurst Declaration and the Position Papers,1999. United Nations and the International Federation of Surveyors. Workshop, 18-22 October 1999.

[7] Williamson, I, \& Grant, a D M, United Nations-FIG Bathurst Declaration on Land Administration for Sustainable Development: Development and Impact. FIG XXII International Congress, Washington, D.C. USA, April 19-26, 2002.

[8] Williamson, I, Enemark, S, Wallace, J, \& Rajabifard, A. Land Administration for Sustainable Development, (2009).

[9] Goodale, M R G, \& Sky, P K, A Comparative Study of Land Tenure, Property Boundaries, and Dispute Resolution : Examples from Bolivia and Norway, 2000.

[10] Anderssen A, The Land Tenure System in Norway, And Local Democracy in Relation to Land Issues. Paper presented at the presented to Highlands and Islands Forum, 1998, Inverness,March 20-22,1998. Retrieved from http://www.caledonia.org.uk/land/tenure.htm

[11] VIII, I H i a A, Hydropower Good Practices:Environment Mitigation Measures and Benefits : case study 10-04: Landscape and cultural Heritage- Aurland Hydropower Development, Norway, 2006. 
[12] WCD, WCD Case Study:The Glomma and Laagen River Basin in Norway, 2000.

[13] Renzhong, G, \& Chengyun, Y, The Legal Framework for land Tenure in China, 2005. Retrieved October $\quad 20, \quad 2010, \quad$ from http://www.fig.net/commission7/bangkok_2005/papers/9_1_guo.pdf

[14] Brown, P. H., \& Xu, Y.Hydropower Development and Resettlement Policy on China's $\mathrm{Nu}$ River, 2009. Forthcoming, Journal of Contemporary China.

[15] Brown, P H, Magee D, \& Xu Y, Socioeconomic vulnerability in China's hydropower development. [doi: DOI: 10.1016/j.chieco.2008.06.002],2008. China Economic Review, 19(4), 614-627.

[16] Yardley J, Dam Building Threatens China's 'Grand Canyon',2004 New York Times, March 10, 2004, from http://chinarivers.com/NYT\%20Article/New\%20York\%20Times\%20Article\%20031020 $\underline{04 . h t m l}$

[17] Ryder G, Analysis:Chinese hydro concessions generate controversy in Cambodia,2008, Retrieved February 15, 2011, from http://www.probeinternational.org/mekong-utilitywatch/analysis-chinese-hydro-concessions-generate-controversy-cambodia

[18] Acharya B R, Land Tenure and Land Registration in Nepal. TS 7B - Administration of Land Tenure,2008, Integrating Generations FIG Working Week 2008, Stockholm, Sweden 14-19 June 2008.

[19] Shah S, Hydropower development in Nepal-Current situation and private sector,2008, presented on May 19th, 2008.

[20] Rai K, Hydropower development in Nepal: Local Responses to Technology and Formal Insitutions,2004, . Conference on International Agricultural Research for development, 5-7 October 2004.

[21] GoN, Interim Consitution of Nepal, 2007. Retrieved February 14, 2011, from http://www.worldstatesmen.org/Nepal_Interim_Constitution2007.pdf

[22] KGEMU, \& Inc, M K I, Impoverishment Risks Monitoring and Management in Kali Gandaki 'A' Hydroelectric Project Beltari, Syangja, Nepal, 2002 